\title{
On the various ways that anadromous salmonids use lake habitats to complete their life history
}

Lennox, Robert J.; Pulg, Ulrich; Malley, Brendan; Gabrielsen, Sven-Erik; Hanssen, Erlend Mjelde; Cooke, Steven J.; Birnie-Gauvin, Kim; Barlaup, Bjørn T.; Vollset, Knut Wiik

Published in:

Canadian Journal of Fisheries and Aquatic Sciences

Link to article, DOI:

10.1139/cjfas-2020-0225

Publication date:

2021

Document Version

Peer reviewed version

Link back to DTU Orbit

Citation (APA):

Lennox, R. J., Pulg, U., Malley, B., Gabrielsen, S-E., Hanssen, E. M., Cooke, S. J., Birnie-Gauvin, K., Barlaup, B. T., \& Vollset, K. W. (2021). On the various ways that anadromous salmonids use lake habitats to complete their life history. Canadian Journal of Fisheries and Aquatic Sciences, 78, 90-100. https://doi.org/10.1139/cjfas2020-0225

\section{General rights}

Copyright and moral rights for the publications made accessible in the public portal are retained by the authors and/or other copyright owners and it is a condition of accessing publications that users recognise and abide by the legal requirements associated with these rights.

- Users may download and print one copy of any publication from the public portal for the purpose of private study or research.

- You may not further distribute the material or use it for any profit-making activity or commercial gain

- You may freely distribute the URL identifying the publication in the public portal 
$11{ }^{1}$ Laboratory for Freshwater Ecology and Inland Fisheries (LFI) at NORCE Norwegian Research

\section{On the various ways that anadromous salmonids use lake habitats to complete their life} history Accepted for publication in Canadian Journal of Fisheries and Aquatic Sciences
Robert J. Lennox ${ }^{1 *}$, Ulrich Pulg ${ }^{1}$, Brendan Malley ${ }^{2}$, Sven-Erik Gabrielsen ${ }^{1}$, Erlend M. Hanssen $^{1}$, Steven J. Cooke ${ }^{3}$, Kim Birnie-Gauvin ${ }^{4}$, Bjørn T. Barlaup ${ }^{1}$, Knut Wiik Vollset ${ }^{1}$ 8

(1)

(1)

2

13

\author{
Centre, Nygårdsporten 112, 5008 Bergen, Norway \\ ${ }^{2}$ Department of Fisheries and Oceans Canada, Winnipeg, MB
}

4

${ }^{3}$ Fish Ecology and Conservation Physiology Laboratory, Department of Biology, Carleton

6

\section{University, Ottawa ON}

${ }^{4}$ Section for Freshwater Fisheries and Ecology, National Institute of Aquatic Resources, Technical University of Denmark, Vejlsøvej 39, 8600 Silkeborg, Denmark

9

*Author to whom correspondence should be addressed, e-mail: role@ norceresearch.no;

$$
\text { tlf: +4791194442 }
$$




\section{Abstract}

26 Despite the preponderance of exorheic lakes in rivers home to anadromous salmonids, little

27 research has focused on how salmon, trout, and charr use lakes as part of their anadromous life

28 histories. The literature on this subject has so far revealed that some parr move into lakes to feed

29 and grow before smoltification but that smolts moving through lakes tend to have high mortality

30 in disproportion to what is observed in other habitats they migrate in or through. Adults have been

31 observed using lakes for behavioural thermoregulation prior to spawning and kelts of iteroparous

32 species often exploit lakes to overwinter before returning to sea to recondition. We summarized

33 knowledge on lakes as salmonid habitat and identified knowledge gaps about the use of lakes by

34 anadromous salmonids related to whether lakes are barriers that structure genetics of populations,

35 whether mortality in lakes is compensatory or additive, and whether systems with lakes have 36 higher rates of repeat spawning among iteroparous salmonids. Human activities that alter lakes

37 require further study to understand how changes in temperature, oxygen, ice, or circulation affect 38 navigation and fate.

40 Keywords - lacustrine, reservoir, salmon, trout, charr, migration, restoration 


\section{Introduction}

Salmonids (Subfamily Salmoninae) are distributed throughout the Holarctic in rivers,

44 creeks, streams, ponds, and lakes. Species in this family are exceptional colonizers and have

45 great capacity to move into saltwater to exploit the feeding opportunities provided by estuaries

46 and coastal seas as well as the open ocean (Klemetsen et al. 2003; Drenner et al. 2012). The

47 anadromous salmonids include species from the genera Salvelinus, Oncorhynchus, Salmo, and

48 Parahucho. These species are riverine but many populations encounter lakes as part of their life

49 cycle, including during migration to sea for feeding and eventually returning to spawn in the

50 rocky gravel substrate where they hatched or overwinter (Klemetsen et al. 2003; Hendry et al.

51 2004). Habitat is a primary focus of much research on anadromous salmonids (Jonsson and

52 Jonsson 2011), including experiments to determine how water chemistry (Peterson and Gale

53 1991), substrate (Pulg et al. 2019; Finstad et al. 2009), and temperature (Richter and Kolmes

54 2005; Frechette et al. 2018) influence the ability of salmonids to colonize and thrive in

55 freshwater.

56 Anadromous salmon, trout, and charr are native to freshwater systems that vary from

57 large arctic lakes (e.g. Baker Lake in Kivalliq, Nunavut and Nettilling Lake in Qikiqtaaluk,

58 Nunavut), to rivers thousands of kilometers long (e.g. Fraser River, British Columbia), to small

59 creeks accessible only during the spring freshet (Ar Brook, Sweden; Limburg et al. 2001). The

60 great diversity in the habitat types available to salmonids means that the freshwater ecology of

61 salmon can differ greatly as an adaptation to life in their unique home system (Jonsson et al.

62 1991). For example, brown trout (Salmo trutta) living in small streams around the Baltic Sea

63 may migrate into estuaries as parr to cope with low flows that preclude growth opportunities for 
64 young of the year in freshwater (Limburg et al. 2001). However, not all anadromous rivers are

65 simply linear systems connecting with the sea; many post-glacial watersheds are characterized by

66 the presence of exorheic lakes, which are large, widened areas of very slow flowing water $(<$

$670.01 \mathrm{~m} \mathrm{~s}^{-1}$ ), often with an inlet to the upper reaches of the river and always an outlet to the lower

68 reaches of the river. The reliance on lake habitats varies among salmonids, for salmonids such as

69 sockeye salmon, lake stratification may provide an opportunity for behavioural thermoregulation

70 during an extensive migration (Newell and Quinn 2005). For anadromous Arctic charr

71 (Salvelinus alpinus), lacustrine environments are essential to most populations at various life-

72 history stages, including reproduction, juvenile rearing, and over-wintering (Johnson 1980,

73 Power 2002, Moore et al. 2017). Lakes provide different habitat to anadromous salmonids in

74 their riverine home that makes systems that incorporate lakes of particular peculiarity in the life 75 cycle of salmonids.

76 Hundreds of systems that support anadromous populations of salmon, trout, and charr

77 have lakes. Yet, most data about the life cycle and migration of salmonids is limited to fluvial

78 rivers stretches without lakes. Seminal reviews about the biology of salmonids (e.g. Klemetsen et

79 al. 2003; Birnie-Gauvin et al. 2019) and even the biology of salmon in freshwater (e.g.

80 Bardonnet and Bagliniere 2000; Arostegui and Quinn 2019) note the use of lakes by anadromous

81 salmon, trout, and charr and open the opportunity for a more comprehensive discussion of their

82 biology in lakes. Investigation of the biology of anadromous salmonids in lakes begins to reveal

83 the unique patterns in the life cycles and migrations of salmonids through lakes including the

84 spawning habitats for some species, the growth opportunities offered to parr, the challenges

85 confronted by smolts moving through lakes, the thermoregulatory opportunities conferred by

86 lakes to adults, and the refuge for reconditioning exploited by post-spawning kelts (e.g. 
87 Hutchings 1986; Newell and Quinn 2005; Kennedy and Allen 2016; Mulder et al. 2018). This

88 literature is still diffuse and represents a minority of research on anadromous salmonids, but

89 demonstrates that there is a uniqueness to biology in lakes that necessitates more focused

90 research. There are ultimately two main questions that must be addressed with respect to the use

91 of lakes by anadromous salmonids: 1) how do lakes affect production of anadromous salmonids

92 and 2) how do lakes influence the pattern of migration expressed by anadromous salmonids. In

93 this review, we seek answers to these questions in the literature and identify where gaps exist in

94 our knowledge that limit the resolution of how lakes affect the production and migration of

95 salmon, trout, and charr. Our aims are to illustrate how lakes fit within the paradigm of salmonid

96 migrations and identify priorities for better understanding how this group of fishes of high

97 cultural and economic importance exploits this understudied habitat type throughout its

98 distribution.

99

100 What is a lake and what type of lakes are there in the context of salmonids?

101

102

Five major types of lakes are distinguished in the Holarctic, referring to their

103 geomorphological origin (Hutchinson 1957): 1) tectonic lakes such as rift lakes (e.g.

104 Thingvallavatn, Iceland $64.1954^{\circ} \mathrm{N}, 21.1374^{\circ} \mathrm{W}$ ); 2) volcanic lakes such as crater lakes (e.g.

105 Pulvermaar, Germany $50.1310^{\circ} \mathrm{N}, 6.9250^{\circ} \mathrm{E}$ ); 3) glacial lakes such as Lochs (e.g. Vangsvatnet,

106 Norway $60.6187^{\circ} \mathrm{N}, 6.3250^{\circ} \mathrm{E}$ ); 4) fluvial lakes, such as oxbows (e.g. Carter Lake, USA,

$10741.301889^{\circ} \mathrm{N},-95.914917^{\circ} \mathrm{E}$ ); and 5) artificial lakes such as reservoirs (e.g. Kinbasket Lake,

108 Columbia River, Canada $52.1306^{\circ} \mathrm{N}, 118.4362^{\circ} \mathrm{W}$ ). Several more types are described, but they

109 are extremely rare in the home range of salmon species, such as meteorite lakes and solution 
110 lakes. Exorheic lakes are those that are open and have an ultimate connection to the ocean by 111 way of a connected river or stream, distinguished from endorheic counterparts that are closed

112 and have no direct connection to the ocean. Although salmonids may inhabit both endorheic and

113 exorheic lakes, exorheic lakes provide unique habitat to fish that can reach the ocean and use 114 lakes in diverse ways.

115 Most contemporary salmonid habitat has been shaped by glaciation during the ice ages of 116 the Pleistocene. The distribution of anadromous salmonids in Europe, Asia, and North America

117 overlaps very closely with the last glacial maximum 20000 years ago. Only parts of Alaska, the 118 western United States, and pockets of central Europe were ice-free. Where the glacier has

119 receded, numerous lakes were formed and glacial lakes are the most numerous in the world 120 (Cohen 2003). On sedimentary terranes, most valleys where lakes could form have been filled 121 with sediments in the Holocene. Lakes are therefore rare in these landscapes (Hauer and Pulg 122 2020). On plutonic and metamorphic terranes, post-glacial rivers often develop a characteristic 123 semi- and non-fluvial morphology, including the formation of lakes. Drainages are usually 124 supply limited, meaning that rivers incise in valley bottoms that are only marginally covered 125 with sediments (Hauer and Pulg 2018). In these regions, most lakes formed by the ice during the 126 Pleistocene have endured. Such regions are dominating the Scandinavian shield, the east

127 Canadian Shield, Greenland, and Scotland as well as minor parts of Alaska and British

128 Columbia. In these regions, salmonids find many more lakes than on the sedimentary terranes 129 and fluvial rivers south of the glaciated area such as parts of Germany, France, Maine,

130 California, or Oregon. Salmonids must therefore have survived the Pleistocene glaciation periods 131 in fluvial river systems not covered by glaciers that are characterized by having fewer lakes, 
132 reentering the lake-rich post-glacial habitats re-emerging from the glaciers in the Holocene a

133 relatively short time ago (approx. 10000 years; McCusker et al. 2000; Olafsson et al. 2014).

134 Compared to rivers, lakes have little current $\left(<0.01 \mathrm{~ms}^{-1}\right)$ but current is not completely

135 absent. Natural lakes in the home range of salmonids are usually stratified when deeper than 5-10

$136 \mathrm{~m}$. Water has its highest density at $4{ }^{\circ} \mathrm{C}$ and lakes thus develop a characteristic bottom layer of 4

$137{ }^{\circ} \mathrm{C}$ (hypolimnion) with warmer layers in summer or colder layers in winter on top (epilimnion).

138 When the temperature in the epilimnion reaches close to $4{ }^{\circ} \mathrm{C}$, stratification collapses and water

139 can be mixed by currents driven by mainly wind and river inlets (Wetzel 2001). In dimictic

140 lakes, lake turnover happens in spring and autumn, in monomictic lakes this happens once a year

141 (summertime in the Arctic). Salmonids use both the hypo- and epilimnion. Spawning of sockeye

142 occurs mainly in the epilimnion (0-5 m; Leonetti 1997). If oxygenated, the hypolimnion provides

143 a permanent thermal refuge with cool water $\left(4^{\circ} \mathrm{C}\right)$ that is essential for salmonids, especially in

144 southern parts of their distribution (Eloranta et al. 2013).

145 River-fed lakes with a short retention time, i.e. small ratio of volume relative to river

146 discharge, do not develop stratification. From a limnological perspective, such low-ratio lakes

147 can be considered pools in a river rather than a lake, and they have complex currents and eddies

148 dissimilar to lakes. Artificial lakes in salmonid rivers are usually created by damming (reservoirs

149 and impoundments). Deep and large reservoirs develop stratification, but water levels may vary

150 largely and affect food webs and life histories of fish (Murphy et al. 2019). Dams can alter

151 downstream thermal regimes (Dripps and Granger 2013), for example, water discharged from

152 bottom intakes in such lakes can therefore be colder than upstream reaches of rivers, with

153 consequences for phenology, growth, and community dynamics within rivers. Spawning may

154 therefore be later and growth slower in downstream reaches. Shallow impoundments that are 
155 common in run of the river hydropower stations usually do not stratify but slow the water current

156 significantly and may thus influence migration speed, navigation, and vulnerability to predators

157 (Jepsen et al. 1998).

158 Lakes function as sediment traps. Fluvially transported material from inlet rivers and 159 colluvial material from mountain slopes accumulates in lakes. Due to slow velocity and shear

160 stress, lacustrine sediments are often dominated by fine sediments $(<1 \mathrm{~mm})$ and provide

161 characteristic stratifications that may reflect past discharge events and bed load transport of

162 tributaries (Hauer et al. 2019). This may create opportunities for studying anadromous

163 populations in sediment cores (e.g. Gregory-Eaves et al. 2009). However, coarser material such

164 as gravel and boulders may occur, especially at river inlets, at colluvial fans, and at the shore

165 where waves and changing water levels create larger shear stress. These particular areas may be

166 especially important for salmonids given they provide spawning habitat for anadromous

167 salmonids in some watersheds (Arostegui and Quinn 2019).

168

169 On the ways that anadromous salmonids exploit lakes

170

171 Growth habitat for parr

172

173 Anadromous lakes provide substantial potential habitat for the production of salmonids

174 although not all species exploit these habitats (Arostegui and Quinn 2019). For species such as

175 brown trout, sockeye, and Atlantic salmon, rearing in lakes may support a significant proportion

176 of a population's output in some systems (e.g. Atlantic salmon; Chadwick and Green 1985).

177 Most colonization of lakes by juvenile salmonids seems to be immigration of parr spawned in the 
178 lake inlet, outlet, or tributaries (Halvorsen et al. 1996) or even farther away. Bodznick et al.

179 (1978) showed olfactory preference for lake water among sockeye fry, suggesting an early life

180 migration from the river to these lake habitats for rearing. Tests on sockeye salmon

181 (Oncorhynchus nerka) fry from Alaska revealed genetic differences among lake-spawned,

182 tributary-spawned, and outlet-spawned salmon suggesting inherent differences driving behaviour

183 and early life habitat selection (Raleigh 1967). Salmonid species seem to use lakes differently for

184 rearing; sockeye salmon are described as limnetic zooplanktivores or insectivores with diel

185 vertical migration (Eggers 1978; Richardson et al. 2017). Pepper et al. (1985) explained that

186 Atlantic salmonids thrive better in shallow lakes and preferentially colonize the littoral zone near

187 shore. In addition, Godiksen et al. (2012) described a difference in temperature use at age for

188 Arctic Charr, with young-of-the-year Arctic charr are also found in warmer, littoral habitats but

189 shifting to colder habitats between 1-3 years of age (Godiksen et al. 2012). There is likely a

190 broad variation in habitat quality among lakes, but they appear to provide good habitat for

191 salmonids; comparison of proximate body composition between Atlantic salmon of fluvial and

192 lacustrine provenance revealed higher protein and fat content among the lacustrine samples

193 (Dempson et al. 2004). Contrastingly, Arctic charr parr from rivers grew faster than lake-

194 dwelling individuals (Gulseth and Nilssen 1999). Although lake production of anadromous

195 salmonids can be high, there may be other limiting factors that temper the potential production

196 and growth of salmon, trout, and charr in lakes.

197 Competition and predation are important factors determining the suitability of lakes for

198 salmonid parr to colonize and exploit for growth. It has been suggested that lake colonization by

199 Atlantic salmon parr is a response to competitive exclusion by conspecifics in the river.

200 Interspecific competition may be a driving force behind lake use by sockeye salmon, which share 
201 rivers with congeneric chinook (O. tshawytscha), coho (O. kisutch), pink (O. gorbuscha), chum

202 (O. keta), and rainbow (O. mykiss). The extent of trophic segregation when these species co-

203 occur may be ascertained through experimental designs or comparisons between allopatric and

204 sympatric systems. Trout dominated Atlantic salmon and Arctic charr in most lakes in northern

205 Norway but the observation that salmon and charr dominated others suggests there are

206 mechanisms of competition that differ across environments (Halvorsen et al. 1996). Charr were

207 excluded from the shallow littoral zone in many systems but dominated in lakes with deep secchi

208 depth (Halvorsen et al. 1996). In western Norway, competition between charr and trout was

209 mediated both by individual size and water temperature; trout displaced charr either deeper in the

210 littoral or into the pelagic zone (Gabrielsen et al. 1999). Niche segregation may also be

211 attributable to trophic differences among species (Jansen et al. 2002). Contrary to suggestions

212 that lake-dwelling parr are pushed there by competitive exclusion, several studies reveal fast

213 growth among parr rearing in lakes, suggesting life in anadromous lakes may be beneficial

214 (Hutchings 1986; Erkinaro et al. 1995; Halvorsen and Svenning 2000; Dempson et al. 2004).

215 Whether this affects the rate of smoltification or maturation is unknown, but there may be more

216 temperature choice available in lakes than in rivers to optimize growth.

217 The presence of other lake-dwelling species may exclude salmon from exploiting lakes;

218 O'Connell and Ash (1989) suggested that the absence of pike and cyprinids was the reason for

219 high abundances of salmon parr in anadromous lakes of Newfoundland compared to mainland

220 rivers. Lake trout (Salvelinus namaycush), dolly varden (Salvelinus malma), bull trout

221 (Salvelinus confluentus), and European grayling (Thymallus thymallus) are also among the

222 salmonid species that may co-occur in Arctic, Pacific, and Atlantic lakes. However, sticklebacks

223 are also commonly co-occurring, and Richardson et al. (2017) revealed significant dietary 
224 differences between sockeye salmon and threespine stickleback (Gasterosteus aculeatus) in a

225 shallow Alaskan lake. In winter, Swales et al. (1988) observed significant catches of coho parr in

226 anadromous lakes but attributed higher catches of parr in one lake to the relatively low

227 abundance of threespine stickleback, suggesting competition mediated colonization of the lakes

228 by coho. In addition to competition, predation has great potential to operate as a mechanism

229 affecting lake exploitation by anadromous salmonids. At high latitudes where freshwater

230 environments are less productive, resource pulse adapted species such as Dolly Varden

231 (Salvelinus malma) depend on cohabiting salmonids within lakes. Armstrong and Bond (2013)

232 described how dolly varden gorge on Pacific salmon eggs, nearly accumulating their annual

233 energy surplus needs in $\sim 5$ weeks. Predators may also drive the behaviour of young salmon in

234 lakes. Eggers (1978) observed diel vertical migration among zooplanktivorous sockeye salmon

235 smolts in Lake Washington and inferred high rates of crepuscular feeding based on stomach

236 fullness. Rapid growth of juvenile sockeye in the summer yielded to null or negative growth in

237 the winter as feeding was greatly reduced, likely to offset risk of predation by northern

238 pikeminnow (Ptychocheilus oregonensis). Parr may school in the deep limnetic zone of lakes

239 during the day before ascending to the shallows to feed on copepods and cladocerans (Narver

240 1970). Invasive predators may exclude salmonids from lakes, including bass (Micropterus

241 dolomieu) and pickerel (Esox niger) in Nova Scotia.

$242 \quad$ Fry and parr of many anadromous salmonids may spend short or prolonged periods

243 rearing in lakes before smoltification. Sampling these early life stages is needed to better survey

244 how important these habitats are to various species, particularly those not well resolved with

245 respect to lake use. Arostegui and Quinn (2019) report on some seemingly exceptional examples

246 of lake use by pink, chum, coho, and chinook that suggests more research might reveal new 
247 knowledge about lake usage by these species. How community dynamics facilitate or antagonize

248 lake colonization and whether juvenile anadromous salmonids benefit from different temperature

249 or food availability in lakes may be relevant to understand how lakes provide heterogeneity to

250 river systems yielding seagoing salmon, trout, and charr.

251

$252 \quad$ Lakes as transitional habitats for migrating smolts

When salmonids undergo smoltification, morphological, physiological and behavioral

255 changes prepare them for life at sea, initiating the downstream migration towards the ocean

256 (Folmar and Dickhoff 1980; McCormick and Björnsson 1994; see review by Thorstad et al.

257 2012). In many catchments, smolts have to migrate through lakes to reach the river outlet.

258 During the riverine migration, salmonids are in a shallow environment of rapid downstream

259 currents. The transition into a lacustrine environment challenges smolts, with less directed

260 currents and formation of eddies potentially confounding navigation. Little is known of the

261 navigational mechanisms guiding salmonid smolts through lakes although flow is likely

262 important in shallow or narrow lakes. Sockeye salmon smolts, a species whose juveniles

263 frequently rears in lakes, have a directional preference towards the lake outlet, apparently using

264 celestial visual orientation (Johnson and Groot 1963); navigational mechanisms are not resolved

265 for other species. Smolts seem to have diel vertical migration within lakes, and Scheuerell and

266 Schindler (2003) observed depths from 75 to $15 \mathrm{~m}$ for sockeye smolts. Telemetry studies of

267 Atlantic salmon smolt reveal that they spend considerable time in lakes, an inefficiency

268 suggesting poor navigation that costs valuable time and energy (Thorpe et al. 1981; Hansen et al.

269 1984, Honkanen et al. 2018; Babin et al. 2020; Hanssen 2020). However, this ignores the 
270 possibility that lakes have a role in the process of smolt maturation, which has not been studied

271 before. Consequently, lakes have been identified as areas of high loss among smolts. In Lough

272 Erne, Northern Ireland, Kennedy et al. (2018) observed a $31.2 \% \mathrm{~km}^{-1}$ mortality in the first

273 kilometers of the lake, suggested to be caused by predation by pike (Esox lucius). In an artificial

274 lake, Jepsen et al. (1998) observed a total 90\% mortality for smolts migrating through Lake

275 Tange, and attributed this to predation by pike and avian predators. High mortality rates (35\%)

276 have also been observed for S. trutta smolts negotiating in artificial impoundments in Denmark

277 (Schwinn et al. 2018). At a lake outlet, Furey et al. (2015) discovered aggregations of bull trout

278 (Salvelinus confluentus) predating on out-migrating sockeye salmon smolts, estimating the total

279 consumption to account for a large portion (up to 12.6 \%) of sockeye biomass. Poe et al. (1991)

280 described pikeminnow, channel catfish, walleye, and smallmouth bass predation on Pacific

281 salmon smolts in fluvial and reservoir reaches of the Columbia River. Encountering the

282 navigational challenges that delay migration, along with entering a habitat potentially rich with

283 piscivorous predators, makes lake areas hotspots for smolt losses; depending on the biology of

284 the predator. Predation may be concentrated at lake inlets (northern pike; Kennedy et al. 2018),

285 outlets (bull trout; Furey et al. 2015 - note, they describe bull trout aggregations at the "edge" of

286 the lake-river interface, presumed to be the outlet), or within the lake (brown trout; Hanssen et al.

287 2020). This corresponds to observations of anti-predator behaviour in lakes including nocturnal

288 migration, schooling, and diel vertical migration (Hartman et al. 1967, Eggers 1978, Thorpe et al.

289 1981; Scheuerell and Schindler 2003).

290 Despite many large lakes in the range of Pacific salmon, research has not focused very

291 much on the migration of the native species through lakes. There are still substantial knowledge

292 gaps related to the migration of smolts through lakes, with most data coming from Atlantic 
293 salmon, which suggests further research is needed on lakes where other smolts species transit.

294 Additionally, with lakes functioning as survival bottlenecks for migrating smolts, research

295 should focus on whether these areas can act as genetic barriers in river systems. Several studies

296 have highlighted the genetic diversity among locations within a river (Burger et al. 1997; Elo et

297 al. 2004; Primmer et al. 2006, Vähä et al. 2008; Larson et al. 2014). A compelling research

298 question is whether adult spawners above and below an anadromous lake differ genetically with

299 adaptation exploit lakes. Brannon (1972) described differences in behaviour of parr born below

300 or above lakes, suggesting innate differences, but whether similar behavioural adaptations exist

301 among smolts to survive downstream through lakes is not known. This is important to consider,

302 because many populations contemporaneously rely on hatchery programs to enhance the smolt

303 production and the genetic source may be relevant to consider to ensure adaptations for efficient

304 lake navigation and survival. Another relevant research question that arises from the high

305 mortalities observed in lakes is what type of functional response is present in the predator prey

306 system. Predator-driven Allee-Bowen effects can threaten small populations when the predator

307 numerical response does not respond to the small prey population (Gascoigne and Lipcius 2004).

308 For species that depend on predator swamping to survive the Type-II functional response of

309 aggregative predators, populations at low abundance, such as small salmon populations, can

310 struggle to recover to pre-impact abundance because of predation (Lennox et al. 2018).

312 Adult salmon refuge in lakes during the upriver spawning migration

314 Adult salmon must survive and thrive in lakes in order to spawn successfully. The

315 navigational mechanisms for moving through lakes remain poorly described. Sockeye salmon 
were described to move up to five times the minimum distance necessary to travel upstream from

317 outlet to inlet based on radio tracking by Young and Woody (2007). Salmon may remain in lakes

318 for months during the migration (premature migration; Quinn et al. 1997; Newell and Quinn

319 2005; Quinn et al. 2016). Rivers with lakes in particularly tend to have more premature

320 migration timing by the salmon, presumably because the population has evolved to exploit the

321 availability of refuge (Reed et al. 2017). In Lough Neagh, Atlantic salmon seemed to ascend

322 lakes slowly until later in the season when time was more limited to make it to spawning grounds

323 (Kennedy and Allen 2016). Diverse and complex lake spawning strategies are emphasized by a

324 two year cycle of migration and maturation (Johnson 1980) in which charr overwinter in Nauyuk

325 Lake, access upstream spawning grounds in Willow Lake during the spring freshet, and spawn

326 more than a year after migration was initiated. Ablation experiments on lake spawning sockeye

327 in Lake Toya, Japan suggest that visual cues are important for finding the general spawning area

328 followed by olfactory sensing for precise fine-scale homing (Ueda et al. 1998). However,

329 displacement experiments by Blair and Quinn (1991) showed that site characteristics serve a role

330 in sockeye spawning site selection because individuals did not consistently return to their capture

331 site. Clearly, salmon, trout, and charr can navigate lakes but require time and perhaps other

332 resources (genetic information, experience from previous spawning or downstream migration as

333 smolt) to enhance passage. Delays in lakes may have both costs and benefits to the individuals

334 that seek out holding territory in preparation for spawning.

335 One of the most substantive implications of lake usage by adult salmonids is the change

336 in temperature encountered relative to the river. The impact that lakes have on the thermal

337 landscape of rivers is considerable and rivers with lakes tend to have earlier migration timing

338 than rivers without (Reed et al. 2017). Lentic water bodies, which are typically stratified, create 
opportunities for behavioural thermoregulation given the manifold effects of water temperature

340 on the biology and ecology of fish. In the Lake Washington basin, it is typical for sockeye

341 salmon to return to the lake during the warmest period of the year and exploit cooler

342 temperatures at depth (Newell and Quinn 2005). Fish typically spent $\sim 6$ days approaching in

343 river water $\sim 18{ }^{\circ} \mathrm{C}$ before entering the lake, which was generally $<13{ }^{\circ} \mathrm{C}$. The majority of

344 temperature records obtained from fish in the lake were between 9 and $11^{\circ} \mathrm{C}$, corresponding to

345 depths of $18-30 \mathrm{~m}$. Fish remained in the lake for an average of 83 days before ascending to

346 spawning grounds. Using a combination of telemetry and thermal loggers, Mathes et al. (2010)

347 inferred that fish were retarding pathogen development by selecting cool temperatures. However,

348 the role of anadromous lakes in behavioural thermoregulation may not apply to all species.

349 Keefer et al. (2019) used radio telemetry and archival thermal loggers to characterize chinook

350 salmon thermal biology during use of impounded reaches of the Columbia and Snake Rivers.

351 Fish in that study exhibited little diel temperature variation but did engage in frequent and

352 extensive vertical movements. During the depth-seeking behaviour, fish did experience slightly

353 cooler body temperatures $\left(\sim 0.01\right.$ to $\left.0.02{ }^{\circ} \mathrm{C} / \mathrm{m}\right)$. However, the authors did not find evidence of

354 long-term (beyond minutes) cool-water thermal refuges in reservoirs. Similarly, Goetz and

355 Quinn (2019) found that adult chinook salmon in Lake Washington spent time both above and

356 below the thermocline and failed to fully exploit the available thermal refuge in deep water.

357 The disparity in findings (especially relative to Newell and Quinn 2005, conducted in the

358 same system) regarding lake use by anadromous salmonids is worthy of more research as we

359 seek to understand intra- and interspecific variation. There is evidence of intraspecific variation

360 with respect to the usage of lakes during the upriver migrating sockeye, for example. Females

361 with lowest levels of somatic energy preferred the coolest temperatures in natal lakes (Roscoe et 
362 al. 2010) and Minke-Martin et al. (2018) combined telemetry, thermal loggers, and non-lethal

363 blood sampling and found that $\sim 33 \%$ of fish occupied temperatures within an optimal

364 temperature window $\left(13.4-19.5^{\circ} \mathrm{C}\right.$; range generated using respirometry in a swim tunnel) where

$365 \geq 90 \%$ of maximum aerobic scope was maintained. There was a positive relationship between

366 time spent in the $\mathrm{T}_{\mathrm{opt}}$ aerobic scope during lake residency with reproductive longevity and an

367 inverse probability of egg retention suggesting successful spawning. This study reveals that

368 behavioural thermoregulation may be particularly important for regulating physiological

369 processes, yet relatively little is known about how use of lake habitats relates to maturation

370 processes. Newell and Quinn (2005) reported that the apparent thermal preference of lake-

371 refuging sockeye salmon decreased over the summer which may be a function of sexual

372 maturation, agreeing with findings by Kennedy and Allen (2016) that later arriving Atlantic

373 salmon navigated lakes more rapidly than early arrivals.

374 Studies on anadromous lake usage by adult salmonids have been largely observational in

375 nature, but one study has implemented an experimental approach. Naughton et al. (2018)

376 assessed behaviour and survival of adult chinook salmon as part of a reintroduction program

377 where fish were released either in a reservoir or immediately downstream of spawning grounds

378 in Oregon. Seventy percent of salmon released into the reservoir entered an upriver tributary

379 after spending a median of 3-95 days in the reservoir. Biologgers recovered from salmon

380 revealed that fish selected temperatures that were 3 to $6^{\circ} \mathrm{C}$ cooler per day in the reservoir than in

381 the river. When cumulative exposure was calculated, researchers revealed that reservoir-released

382 fish had 64 degree days less, on average relative to river-released fish. The cumulative aspects of

383 thermal experience seem to be quite important and should become a focus of recent research. 
In general, almost all of the research on lentic behavioural thermoregulation and

385 physiological energetics has occurred in the Pacific northwest of North America. Atlantic salmon

386 have been observed to modify behaviour to maintain optimal body temperatures in rivers and

387 may capitalize on lakes to do so as well (Frechette et al. 2018). Virtually nothing is known about

388 how other salmon species use lentic systems during upriver migration and the extent to which

389 they benefit or impede migration and fitness. Because water temperature is the master factor, it is

390 clear that not only does behavioural thermoregulation impact energy use and maturation (Minke-

391 Martin et al. 2018), it may also play an important role in retarding pathogen development

392 (Mathes et al. 2010). The complex ways in which fish use lentic habitats during upriver

393 migration presents many fascinating opportunities for behavioural ecologists and physiologists to

394 collaborate.

395

396 Spawning habitat

Salmonids predominantly spawn in fluvial reaches of rivers where gravel interstitial

400 increasingly clear that salmonids can make use of diverse habitats for spawning, including

401 brackish estuaries (Landergren and Vallin 1998), as long as the eggs receive enough oxygen, are

402 not smothered by sediment, are safe from predators, and there is spawning gravel available that

403 attracts the female salmon to construct a redd. Lakes do provide habitat for salmonids to spawn

404 (Arostegui and Quinn 2019 have a comprehensive review of this), but most of the research focus

405 is on resident species. For example, populations of resident lake-spawning brown trout that use

406 wave action (Barlaup et al. 1998; Kleiven and Barlaup 2004) or upwelling areas (Brabrand 2002)

407 to keep gravel clean. Charr will readily construct redds in lakes with suitable gravel, however, 
where redd construction is not feasible, broadcast spawning is documented among resident

409 populations (Sigurjónsdóttir and Gunnarsson 1989). Spawning without making a redd is also

410 practiced by lake trout (Salvelinus namaycush) and does not include the pre-spawning cleaning

411 of gravel as found for nest digging species (Gunn 1995; Esteve et al. 2008). For many species,

412 exploitation of lakes is only at inlets and outlets with flow, which are indeed important spawning

413 areas for many species (Arostegui and Quinn 2019).

414 There is limited evidence of anadromous salmonids spawning in lakes but interesting

415 exceptions. So far, sockeye salmon are the primary anadromous species documented to use the

416 habitat within lakes as spawning grounds, which has been reported in lakes throughout the

417 distribution (Burger et al. 1995). Post-glaciation patterns of habitat emergence may have driven

418 selection for novel spawning phenotypes in sockeye, and there is evidence of genetic

419 differentiation between lake shoreline (also referred to beach spawning) and river spawning

420 individuals in sockeye (Burger et al. 1997; Larson et al. 2014) as well as in a rare ecotype of

421 chum salmon that spawns in Lebedinoe Lake of the Kurilka River, Russia (Zhivotovsky et al.

422 2012). Lake spawning sockeye have distinct run timing phenotypes, arriving later than the river

423 reproducing counterparts (Burger et al. 1995). A multiple-origin introduction experiment

424 suggested that individuals originating from a line of tributary spawning sockeye can contribute to

425 lakeshore spawning (Burger et al. 2000). Exceptional lake spawning by chum salmon has been

426 observed in both North America and Asia (e.g. Zhivotovsky et al. 2012; see Arostegui and Quinn

427 2019). The closest description of another anadromous salmonid spawning within lakes may be

428 Einarsson et al. (1990), who speculated that Atlantic salmon may have been spawning near

429 tributary outlets within a lake in Iceland, but did not make direct observations. Although not

430 directly within the lake, the inlets, outlets, and straits between two lakes where water is flowing 
431 are commonly used for spawning, meaning that lakes provide some suitable spawning habitat for

432 anadromous salmonids (e.g. pink salmon, Fukushima and Smoker 1997). Spawning surveys in

433 Norway have suggested lake outlets to be important for spawning whereas spawning is sporadic

434 at best at inlets.

435 Habitat conditions required and the rather common occurrence of lake spawning in

436 resident populations render lake spawning likely to occur in anadromous populations that has not

437 yet been found/reported. The description of lake spawning sockeye salmon phenotypes was

438 relatively recent in western science and perhaps lakes are more important spawning zones than

439 presently recognized for some other species. Lakes are clearly not the predominant source of

440 spawning habitat for anadromous salmonids but perhaps provide some additional habitat in

441 certain systems. Despite this, the spawning targets assigned at a national level in Norway are

442 calculated in part based on the perimeter of the system and many do not exclude lakes from the

443 calculation, artificially inflating the spawning targets of rivers with lakes (Hindar et al. 2007).

445 Refuge habitat for post-spawners

447 Reproduction is one of the most energetically-costly events for anadromous salmonids,

448 involving migrations from sea to freshwater (sometimes exceeding hundreds of $\mathrm{km}$ ), the

449 development of sexually dimorphic traits, gonadal development, as well as intra-sexual

450 competition (Stearns 1992; Hendry and Berg 1999; Stephens et al. 2008). This has promoted

451 semelparity in several species of salmonid, but iteroparous species/phenotypes must still migrate

452 back to sea after spawning, and do so on a very limited energy budget (Jonsson et al. 1997;

453 Jørgensen et al. 1997; Hutchings et al. 1999). After spawning, iteroparous Atlantic salmon, sea 
454 trout, anadromous Arctic charr, anadromous brook trout, and steelhead are energy-depleted and

455 must be physiologically prepared for marine re-entry before entering seawater (i.e.

456 osmoregulatory processes). In this case, anadromous lakes may act as important refuge habitats

457 for post-spawners to conserve energy before starting their return to sea. Indeed, anadromous

458 lakes are a feature of rivers that can help support greater rates of repeat spawning among

459 iteroparous species (Cunjak et al. 1998).

$460 \quad$ For some fall-spawning species, lakes may serve as overwintering habitats for post-

461 spawners, hypothesized to be due to a combination of low salinity tolerance and critically low

462 winter marine temperatures (Svenning and Gullestad 2002; Elliott and Elliott 2010; Mulder et al.

463 2018). This is particularly well documented for Arctic charr, but less so for other salmonids.

464 Arctic charr lack 'antifreeze' proteins, preventing them from surviving temperatures below -

$465 \quad 0.99^{\circ} \mathrm{C}$ (Fletcher et al. 1988; Svenning and Gullestad 2002). Ice-covered lakes typically range

466 between 0 and $4^{\circ} \mathrm{C}$, and as such may provide thermal refuge for some anadromous salmonids. A

467 study from two lakes in Labrador, Canada, revealed that charr occupy a narrow range of

468 temperatures $\left(0.5-2^{\circ} \mathrm{C}\right)$, thought to be a strategy that minimizes metabolic costs and energetic

469 expenditure to preserve stored resources for overwinter survival and return migration to sea

470 (Mulder et al. 2018). This energy-saving strategy may be necessary for survival, meaning that

471 lakes represent a critical refuge habitat for resource depleted post-spawners. However,

472 overwintering brown trout in Vassbygdi Lake (Aurland River) mostly selected the warmest water

473 available (never less than $4.2^{\circ} \mathrm{C}$ ), suggesting some species-specific optimization of temperature

474 selection to modulate energetic expenditure while overwintering (Lunde 2014). The differences

475 likely reflect the life histories of the animals, and Monsen (2019) revealed that overwintering 
476 trout in the Botn River occupied surface layers and were less active (3-5 m) than Arctic charr,

477 which stayed at 12-15 m deep.

478 Most anadromous salmonids are known to reduce or cease feeding prior to spawning

479 until they return to sea. Exorheic lakes are not documented to provide feeding habitats for

480 anadromous post-spawners. However, sea trout ( $S$. trutta) overwintering in lakes are observed

481 feeding on Atlantic salmon smolts in the springtime (Hanssen 2020). These lakes could provide

482 refuge against predators for post-spawners including mammals such as otters that seem to be

483 successful at taking around or after spawning (Carss et al. 1990). The somewhat limited data

484 available on the use of lakes by post-spawning anadromous salmonids support the idea that lakes

485 serve as refuge to conserve energy, where fish opt for utilizing areas of low variability to

486 improve bioenergetics efficiency, reduce energy consumption and preserve energetic resources

487 for future metabolic demands (e.g. Mulder et al. 2018). Although it may be assumed that

488 overwintering fish are relatively inactive in the slow flowing, cold lakes while waiting for

489 summer, Monsen (2019) calculated that Arctic charr and brown trout were swimming up to 70-

$49080 \mathrm{~km}$ per day within the lake and must have actively been feeding to maintain energy supplies.

491 Generally, studies that have explored the role of lakes for salmonids have centered on

492 lakes as spawning habitat or rearing habitat, or have strictly considered lake-dwelling phenotypes

493 (Arostegui and Quinn 2019). There is a substantial knowledge gap on the use of lakes by

494 anadromous post-spawners, and the existing studies on the topic have focused on Arctic charr.

495 This is perhaps because most systems with exorheic lakes are home to wild Arctic charr, or

496 because charr are known to use lakes extensively. Although some systems are also home to other

497 anadromous salmonids, almost nothing is known about their potential use of lakes after

498 spawning. If the assumption that other anadromous post-spawning salmonids use exorheic lakes 
499 as refuge for energy conservation is correct, there is a great opportunity to explore this strategy

500 as climate change is likely to impact the condition and duration of lake ice cover (Prowse and

501 Brown 2010) and hydropower regulation can alter the temperatures and ice cover on anadromous

502 lakes. Changing ice cover conditions will impact the stability of the lake environment, reduce the

503 availability and duration of stable water temperatures, and therefore impact the conditions that

504 facilitate energy-conserving strategies after spawning, with subsequent negative impacts on

505 survival.

506

Methods to study the ecology of anadromous in lakes

508

One of the biases towards studies of salmonids in rivers compared to lakes is most likely

510 related to the difficulties of obtaining relevant data on fish ecology and habitat in lakes compared

511 to rivers. Capture of anadromous salmonids can be easily done by backpack electrofishing

512 equipment or seine nets in rivers, but such methods have limited suitability in most areas of

513 lakes, though electro fishing boats can be a suitable method in some shallow lakes. On the other

514 hand, other methods that can be used in standing waters such as gill- or trap nets or angling are

515 possible to use, and can be cost-effective particularly for catching large migratory individuals. A

516 crucial consideration here is capture bias, which can occur if sampling gears are

517 disproportionately targeting animals of a certain phenotype. Animal personality affects

518 catchability and also influences traits such as activity and migration (Biro and Post 2008), so care

519 must be taken to gather a representative sample when studying behaviour. It is particularly

520 important to sample at all depths to avoid biasing towards deep or shallow phenotypes or species.

521 Acoustic echo-sounding has been applied to observe smolt migrations in lakes but is non-specific

522 (Groot and Wiley 1965). Telemetry tagging (including simple passive integrated transponders, 
523 acoustic and radio transmitters) is widely used for studying salmonids and has been critical to

524 revealing how these fishes use lakes (e.g. Mathes et al. 2006; Kennedy et al. 2018; Mulder et al.

525 2018). Depth renders the short reading distance of PIT tags ineffective and triangulation with

526 radio tags in lakes is challenging, so acoustic tagging systems are commonly applied, with

527 receiver arrays that can collect fine or coarse scale data on various aspects of behavior with high

528 dimensionality, as well as sensors to reveal aspects of environmental relations (e.g. depth,

529 temperature) or their physiology (e.g. acceleration). Innovations in this field of science include

530 the development of tagging systems that allows accurate identification of predation events (e.g.

531 Hanssen 2020) and open source triangulation systems allowing fine scale 3D tracking (Baktoft et

532 al. 2017). Other sensors are available in logging tags that must be retrieved from the animal to

533 yield information (which can result in survivor bias because recovery of tags from dead

534 individuals is challenging) include heart rate loggers that reveal physiological responses to the

535 environment (Prystay et al. 2020) and magnetometers that reveal orientation and aspects of

536 navigation (Chakravarty et al. 2019); these tools may soon become important to revealing some

537 of the finer scale details of lake use by anadromous salmonids.

538 Other methods which are of particular interest in studying lake ecology of salmonids is

539 the study of sediment cores. Lakes are particularly suitable for these methods because they are

540 natural deposits of sediments, and sediment core samples are widely available from research

541 programs studying paleo records of climate and ecological processes, particularly within botany

542 (Epp et al. 2015). Traditionally studies have used stable isotopes analysis and records of plankton

543 remains (such as diatom scales; Rühland et al. 2008), and have allowed scientists to build

544 historical records going back thousands of years on biomass of salmonids in lakes. The

545 development of highly sensitive molecular methods, such as environmental DNA (in this context 
546 called sediment DNA), will allow even more detailed analysis on lake ecology; using methods

547 such as metabarcoding will enable scientists to get insights into how whole communities vary

548 with salmonid presence and abundance of salmonids in lakes (Nelson-Chorney et al. 2019).

\section{Synthesis of lingering questions and research opportunities}

Lakes are a part of the habitat type available to anadromous salmonids that can drive the

553 expression of different life history traits. Rivers tend to have greater biodiversity than lakes

554 because they offer a greater diversity of habitat (Irz et al. 2006), however, there may be

555 important differences among lakes that drive the biotic interactions of the fauna. The influence of

556 lake scale (size, depth) on use by parr, adults, and post-spawners is an important avenue of

557 research and one that has not been adequately addressed by the available research. Lakes can be

558 relatively narrow, shallow, and straight but we predict that wide, deep lakes with unpredictable

559 bends and contours will be most relevant to contrast with biology in rivers. Deep lakes with

560 thermoclines likely provide the best habitat for salmon to thermoregulate, providing choices of

561 temperature not available in the river. Adding new studies on systems with lakes of varying sizes

562 will assist in better understanding how lakes are exploited by anadromous salmonids.

563 Salmonid behaviour differs in lakes compared to rivers, which has relevant implications

564 for conservation and management of populations. Parr exploit these habitats for feeding and

565 lakes could buffer density-dependent effects of competition that regulate populations in rivers

566 (Pulg et al. 2019). Adults and smolts seem to have difficulty navigating lakes, and this seems to

567 contribute to high smolt mortality when passing through lakes; however, the mechanisms for this

568 remain poorly understood. Observations from acoustic telemetry have suggested a role of 
569 predation on mortality of smolts. A lingering question here is whether predation in these systems

570 is compensatory, acting on fish that were unlikely due to poor condition or simply a consequence

571 of ineffective navigation. Inability to find the lake outlet in a timely manner would likely kill a

572 smolt and Honkanen et al. (2018) observed inefficient movement of smolts. Hanssen (2020) also

573 estimated smolts moving tens of kilometres before finding the exit of the lake, only $6 \mathrm{~km}$ directly

574 from the inlet. Ineffective and energetically inefficient behaviours in lakes may also kill smolts

575 even in the absence of predators, thus separating whether predation pressure on smolts in lakes

576 represents additive mortality is crucial. Salmon are known to overwinter in lakes when they are

577 available (Hubley et al. 2008). Cunjak et al. (1998) specifically pointed to lakes as important for

578 successful reconditioning of iteroparous Atlantic salmon. Comparisons of behaviour and survival

579 between kelts overwintering in lakes, riverbeds, and estuaries are lacking, but presence of lakes

580 may support higher survival of kelts and better contribution of repeat spawning fish (Cunjak et

581 al. 1998).

582 Some systems have multiple lakes that salmon must pass before reaching the ocean and it

583 is unknown whether they learn successful navigation techniques. Experimental displacement

584 studies could be used to test whether smolts that have already passed a lake pass a second lake

585 faster or with higher survival. Perhaps there is a genetic component to surviving this challenge as

586 well, with stock-specific genes separated by lakes or inherited traits from parents that may help

587 offspring navigate these challenges (Elo et al. 2004; Primmer et al. 2006, Vähä et al. 2008). This

588 would be difficult to test directly, but would have immense implications for programs that stock

589 hatchery fish to ensure that the information needed for juveniles to transit lakes is not disrupted

590 by stocking. It also suggests questions about how the creation of artificial reservoirs affect

591 selective pressures in rivers and introduce a barrier to successful smolt migration. 
593 an established field of applied ichthyology. However, exploitation of rivers affects lake habitat

594 generally differently from rivers and coastal areas. Recreational fishing efforts targeting

595 anadromous salmonids tends to be focused in rivers, meaning that salmonids may be less

596 vulnerable to angling when they refuge in lakes, but this remains to be tested directly. Discharge

597 of hypolimnetic water from reservoirs or mountain intakes leads to colder water temperature in

598 summer and warmer in the winter. In lakes, the cold water sinks to the bottom in the summer,

599 altering circulation patterns and potentially disrupting the cues used by salmon smolts when

600 moving through lakes. The cold water in the summer could also provide a thermal refuge to

601 adults as they move through the system, allowing them to save energy if they exploit these areas,

602 but this is unknown.

Tag effects studies are needed to understand whether tagging fish with transmitters

604 affects their survival probability. Acoustically transmitted depth data from smolts tagged by

605 Haugen et al. (2016) revealed unexpected patterns in depth use and may suggest a buoyancy

606 effect of the tag. Such effects would not be expected in rivers that are relatively shallow, but in

607 Lake Evanger, depth data suggested that smolts were sinking to the bottom and remaining there

608 for a short period before reascending and sinking; the pattern repeated for the first few days

609 before smolts achieved a more normal surface diving pattern (Haugen et al. Unpublished Data).

610 Freshwater provides less buoyancy than saltwater meaning that tag effects on buoyancy are

611 likely to be more pronounced in deep lakes than in shallow rivers or the marine environment.

612 Buoyancy compensation by tagged smolts is therefore urgently needed to provide better context

613 to observations made about smolts during their migration in lakes. The same may also apply to

614 adults. Wright et al. (2019) recorded high mortality of tagged adult salmon in snorkel-style sea 
615 cages compared to untagged fish, although no fish died in unmodified cages in which fish had

616 access to the surface, where they regulate the filling of the swim bladder.

617 Many rivers are managed based on the carrying capacity of fish in the river and it is

618 presently uncertain precisely how lakes influence management paradigms. Spawning counts in

619 rivers are generated by snorkel surveys in many rivers (Mahlum et al. 2020); surveys of lakes are

620 rare, but anadromous salmonids in lakes could be monitored by boat, drone, plane, or

621 echosounder. These surveys can be used to estimate total river production based on eggs per

622 spawner and underestimates caused by fish residing in lakes has consequences for fisheries and

623 future management efforts (Forseth et al. 2013). So little is known about lake production of

624 Pacific salmonids other than sockeye and this clearly creates a potential barrier affecting the

625 management of spawning rivers considering how frequently glacial rivers incorporate lakes

626 where salmon can refuge and rear.

627 Lastly, research is needed to understand the constraints that may cause an individual to

628 use a lake. Are certain individuals more likely to use lakes than others, and why? Genetic

629 differences structuring stocks seem to be partly responsible for the use of lakes among sockeye

630 and chum salmons (Burger et al. 1997; Zhivotovsky et al. 2012). Among iteroparous species,

631 individuals that invest more in reproduction are likely more energy-depleted, and may require a

632 place to rest and recondition, such as a lake, if one is nearby. Alternatively, lakes may provide an

633 intermediate location to recondition given that species such as sea trout are observed foraging in

634 lakes before returning to sea (Hanssen 2020). On the other hand, due to the greater availability of

635 food items at sea, it may be more advantageous to return to sea sooner to recondition. These

636 types of questions would help scientists understand the drivers of these different life-history

637 strategies, and the role of physiology in that context. 


\section{Summary and Conclusions}

Exorheic lakes provide important habitat to Pacific and Atlantic salmon, steelhead, sea

642 trout, Arctic charr, and other anadromous salmonids. Lakes may provide refuge from

643 temperature, flow, predators, and anglers and provide a large volume of potential habitat for

644 supporting fish production, if the species can use it effectively. Many salmonid-producing rivers

645 incorporate lakes but these areas have been scarcely studied compared to rivers without lakes or

646 riverine reaches of rivers with lakes. Consequently, most general models of salmon and trout

647 migrations exclude the movement down and back up through lakes. Parr may also find good

648 feeding habitat in lakes that can contribute to smolt production or encourage better growth or

649 higher rates of residency in partially migratory species such as brown trout, rainbow trout, and

650 Arctic charr; perhaps also maturation as parr if feeding conditions are especially good (Myers et

651 al. 1986). Smolts consistently have high mortality in these areas and there may be unstudied

652 genetic factors or learning involved in assisting migration through lakes, but perhaps the smolt

653 production in lakes acts to offset some of the mortality among smolts. Atlantic salmon and sea

654 trout kelts seem to overwinter in lakes and systems with lakes may have better contributions of 655 repeat spawning (Cunjak et al. 1998). 


\section{References}

659 Armstrong, J.B. and Bond, M.H. 2013. Phenotype flexibility in wild fish: Dolly Varden regulate assimilative capacity to capitalize on annual pulsed subsidies. J. Anim. Ecol. 85(5): 966975.

Arostegui, M.C. and Quinn, T.P. 2019. Reliance on lakes by salmon, trout and charr (Oncorhynchus, Salmo and Salvelinus): An evaluation of spawning habitats, rearing

Babin, A.B., Ndong, M., Haralampides, K., Peake, S., Jones, R.A., Curry, R.A., and Linnansaari, T. 2020. Migration of Atlantic salmon (Salmo salar) smolts in a large hydropower reservoir. Can. J. Fish. Aquat. Sci. 00: 00-00.

Bardonnet, A. and Baglinière, J.L. 2000. Freshwater habitat of Atlantic salmon (Salmo salar). Can. J. Fish. Aquat. Sci. 57: 497-506.

673 Barlaup, B. ., Hindar, A., Kleiven, E., and Høgberget, R. 1998. Incomplete mixing of limed water and acidic runoff restricts recruitment of lake spawning brown trout in Hovvatn, southern Norway. Env. Biol. Fish. 53(1): 47-63.

676 Biro, P.A. and Post, J.R. 2008. Rapid depletion of genotypes with fast growth and bold personality traits from harvested fish populations. Proc. Nat. Acad. Sci. 105: 2919-2922. 
678 Blair, G.R. and Quinn, T.P. 1991. Homing and spawning site selection by sockeye salmon 679 (Oncorhynchus nerka) in Iliamna Lake, Alaska. Can. J. Zool. 69:176-181.

680 Bodznick, D. 1978. Water source preference and lakeward migration of sockeye salmon fry 681 (Oncorhynchus nerka). J. Comp. Phys. 127: 139-146.

682 Brabrand, Å., Koestler, A.G., and Borgstrøm, R. 2002. Lake spawning of brown trout related to 683 groundwater influx. J. Fish Biol. 60(3): 751-763.

684 Brannon, E.L. 1972. Mechanisms controlling migration of sockeye salmon fry (Doctoral 685 dissertation, University of Washington).

686 Burger, C.V., Finn, J.E., and Holland-Bartels, L. 1995. Pattern of shoreline spawning by sockeye 687 salmon in a glacially turbid lake: evidence for subpopulation differentiation. Trans. Am. Fish. Soc. 124(1): 1-15.

Burger, C.V., Scribner, K.T., Spearman, W.J., Swanton, C.O., and Campton, D.E. 2000. Genetic contribution of three introduced life history forms of sockeye salmon to colonization of Frazer Lake, Alaska. Can. J. Fish. Aquat. Sci. 57: 2096-2111.

Burger, C.V., Spearman, W.J., and Cronin, M.A. 1997. Genetic differentiation of sockeye salmon subpopulations from a geologically young Alaskan lake system. Trans. Am. Fish. Soc. 126: $926-938$.

Carss, D. N., Kruuk, H., and Conroy, J. W. H. (1990). Predation on adult Atlantic salmon, Salmo salar L., by otters, Lutra lutra (L.), within the River Dee system, Aberdeenshire, Scotland. J. Fish Biol. 37(6) 935-944.

Chadwick, E. M. P., and Green, J. M. 1985. Atlantic salmon (Salmo salar L.) production in a largely lacustrine Newfoundland watershed: With 1 figure and 5 tables in the text. 
Internationale Vereinigung für theoretische und angewandte Limnologie:

$701 \quad$ Verhandlungen, 22(4), 2509-2515.

702 Chakravarty, P., Maalberg, M., Cozzi, G., Ozgul, A., and Aminian, K. 2019. Behavioural

703 compass: animal behaviour recognition using magnetometers. Move. Ecol. 7: 28.

704 Cohen, A.S. (2003). Paleolimnology: the history and evolution of lake systems. Oxford

$705 \quad$ University Press.

706 Cunjak, R.A., Prowse, T.D., and Parrish, D.L. 1998. Atlantic salmon (Salmo salar) in winter:"

707 the season of parr discontent"? Can. J. Fish. Aquat. Sci. 55: 161-180.

708 Dempson, J.B., Schwarz, C.J., Shears, M., and Furey, G. 2004. Comparative proximate body

709 composition of Atlantic salmon with emphasis on parr from fluvial and lacustrine

710 habitats. J. Fish Biol. 64(5): 1257-1271.

711 Drenner, S.M., Clark, T.D., Whitney, C.K., Martins, E.G., Cooke, S.J., and Hinch, S.G. 2012. A

712 synthesis of tagging studies examining the behaviour and survival of anadromous

713 salmonids in marine environments. PloS One, 7: e31311.

714 Dripps, W. and Granger, S.R. 2013. The impact of artificially impounded, residential headwater

715 lakes on downstream water temperature. Environ. Earth Sci. 68: 2399-2407.

716 Eggers, D.M. 1978. Limnetic feeding behavior of juvenile sockeye salmon in Lake Washington

717 and predator avoidance 1. Limnol. Oceanogr. 23(6): 1114-1125.

718 Einarsson, S.M., Mills, D.H., and Johannsson, V. 1990. Utilisation of fluvial and lacustrine

719 habitat by anadromous Atlantic salmon, Salmo salar L., in an Icelandic watershed. Fish.

$720 \quad$ Res. 10(1-2): 53-71. 
721 Elliott, J., and Elliott, J. A. 2010. Temperature requirements of Atlantic salmon Salmo salar, 722 brown trout Salmo trutta and Arctic charr Salvelinus alpinus: predicting the effects of $723 \quad$ climate change. J. Fish Biol. 77(8): 1793-1817.

724 Elo, K., Vuorinen, J.A., and Niemelä, E. 1994. Genetic resources of Atlantic salmon (Salmo 725

Erkinaro, J., Shustov, Y., and Niemelä, E. 1995. Enhanced growth and feeding rate in Atlantic salar L.) in Teno and Näätämö Rivers, northernmost Europe. Hereditas. 120(1): 19-28. salmon parr occupying a lacustrine habitat in the River Utsjoki, northern Scandinavia. J.

Fish Biol. 47(6): 1096-1098.

Esteve, M. 2005. Observations of spawning behaviour in Salmoninae: Salmo, Oncorhynchus and Salvelinus. Rev. Fish Biol. Fish. 15(1-2):1-21.

Finstad, A. G., Einum, S., Ugedal, O., and Forseth, T. (2009). Spatial distribution of limited resources and local density regulation in juvenile Atlantic salmon. J. Anim. Ecol. 78(1): 226-235.

Fletcher, G.L., Kao, M.H., and Dempson, J.B. 1988. Lethal freezing temperatures of Arctic char and other salmonids in the presence of ice. Aquaculture. 71(4): 369-378.

Folmar, L.C. and Dickhoff, W.W. 1980. The parr-Smolt transformation (smoltification) and seawater adaptation in salmonids: A review of selected literature. Aquaculture. 21: 1-37.

Forseth, T., Fiske, P., Barlaup, B., Gjøsæter, H., Hindar, K., and Diserud, O.H. 2013. Reference point based management of Norwegian Atlantic salmon populations. Environ. Conserv. 40(4): 356-366.

Frechette, D.M., Dugdale, S.J., Dodson, J.J., and Bergeron, N.E. 2018. Understanding summertime thermal refuge use by adult Atlantic salmon using remote sensing, river 
temperature monitoring, and acoustic telemetry. Can. J. Fish. Aquat. Sci. 75(11): 19992010.

745 Fukushima, M., and Smoker, W.W. 1997. Determinants of stream life, spawning efficiency, and spawning habitat in pink salmon in the Auke Lake system, Alaska. Can. J. Fish. Aquat. Sci., 54(1): 96-104.

Furey, N.B., Hinch, S.G., Lotto, A.G., and Beauchamp, D.A. 2015. Extensive feeding on sockeye salmon Oncorhynchus nerka smolts by bull trout Salvelinus confluentus during initial outmigration into a small, unregulated and inland British Columbia river. J. Fish

752 Gabrielsen, S.E. 1999. Effects of fish-farm activity on the limnetic community structure of brown trout, Salmo trutta, and Arctic charr, Salvelinus alpinus. Environ. Biol. Fish. 55(3): 321-332.

757 Godiksen, J.A., Power, M., Borgstrøm, R., Dempson, J.B., and Svenning, M.A. 2012. Thermal habitat use and juvenile growth of Svalbard Arctic charr: evidence from otolith stable

Gascoigne, J.C. and Lipcius, R.N. 2004. Allee effects driven by predation. J. Appl. Ecol. 41: 801-810. oxygen isotope analyses. Ecol. Freshw. Fish. 21(1): 134-144.

Goetz, F.A., and Quinn, T.P. 2019. Behavioral thermoregulation by adult Chinook salmon (Oncorhynchus tsliawytscha) in estuary and freshwater habitats prior to spawning. Fish. Bull. 117(3): 258-275.

Goniea, T.M., Keefer, M.L., Bjornn, T.C., Peery, C.A., Bennett, D.H., and Stuehrenberg, L.C. 2006. Behavioral thermoregulation and slowed migration by adult fall Chinook salmon in 
response to high Columbia River water temperatures. Trans. Am. Fish. Soc. 135: 408419.

767 Gregory-Eaves, I., Selbie, D.T., Sweetman, J.N., Finney, B.P., and Smol, J.P. 2009. Tracking 768 sockeye salmon population dynamics from lake sediment cores: A review and synthesis. In Challenges for diadromous fishes in a dynamic global environment. American Fisheries Society, Symposium (Vol. 69, pp. 379-393).

Groot, C. and Wiley, W. L. 1965. Time-lapse photography of an ASDIC echo-sounder PPI-scope as a technique for recording fish movements during migration. J. Fish. Res. Board Can. 22: $1025-1034$.

Gulseth, O.A., and Nilssen, K.J. 1999. Growth benefit from habitat change by juvenile highArctic char. Trans. Am. Fish. Soc. 128(4):593-602.

Gunn, J.M.1995. Spawning behavior of lake trout: effects on colonization ability. J Great Lakes Res. 21(Suppl 1) :323-329

Halvorsen, M., and Jørgensen, L. (1996). Lake-use by juvenile Atlantic salmon (Salmo salar L.) and other salmonids in northern Norway. Ecol. Freshw. Fish. 5(1), 28-36.

Halvorsen, M., and Svenning, M.A. 2000. Growth of Atlantic salmon parr in fluvial and lacustrine habits. J. Fish Biol. 57(1): 145-160.

Hansen, L.P., Jonsson, B., and Døving, K. B. 1984. Migration of wild and hatchery reared smolts of Atlantic salmon, Salmo salar L., through lakes. J. Fish Biol. 25: 617-623.

Hanssen, E.M. 2020. Novel telemetry predation sensors and mechanistic models reveal the tribulations of Atlantic salmon (Salmo salar) smolts migrating through lakes (Master's thesis, The University of Bergen). 
Hartman, W.L., Heard, W.R., and Drucker, B. 1967. Migratory behavior of sockeye salmon fry and smolts. J. Fish. Res. Board Can. 24: 2069-2099.

Hauer, C., and Pulg, U. 2018. The non-fluvial nature of Western Norwegian rivers and the implications for channel patterns and sediment composition. Catena. 171: 83-98.

791 Hauer, C., and Pulg, U. 2020. Buried and forgotten-The non-fluvial characteristics of postglacial rivers. Riv. Res. Appl. 00: 00-00.

Hauer, C., Holzapfel, P., Tonolla, D., Habersack, H., and Zolezzi, G. 2019. In situ measurements of fine sediment infiltration (FSI) in gravel-bed rivers with a hydropeaking flow regime. Earth Surf. Proc. Land. 44(2): 433-448.

Haugen, T.O., Ulvund, J. B., Lunde, R., Kristensen, T., Barlaup, B.T., and Urke, H.A. 2016. Vandringsmønster og overleving hjå laksesmolt frå Bolstadelva og Vosso.

Hendry, A. P., Castric, V., Kinnison, M. T., and Quinn, T. P. (2004). The evolution of philopatry and dispersal. In Evolution Illuminated. Salmon and their Relatives (eds. A.P. Hendry and S.C. Stearns), 52-91. New York: Oxford University Press

Hendry, A.P., and Berg, O.K. 1999. Secondary sexual characters, energy use, senescence, and the cost of reproduction in sockeye salmon. Can. J. Zool. 77: 1663-1675.

Hindar, K., Diserud, O., Fiske, P., Forseth, T., Jensen, A. J., Uggedal, O., ... and Sægrov, H.

805 Honkanen, H. M., Rodger, J. R., Stephen, A., Adams, K., Freeman, J., and Adams, C. E. 2018.

806 Counterintuitive migration patterns by Atlantic salmon Salmo salar smolts in a large 807 lake. J. Fish Biol. 93(1): 159-162. 
808

809

810

811

812

813 Hutchings, J. A., Pickle, A., McGregor-Shaw, C. R., and Poirier, L. 1999. Influence of sex, body

814

815

816

817

818

819

820

821

822

823

824

825

826

827 Johnson, L. 1980. The arctic charr, Salvelinus alpinus. In Balon, E. K. (ed). Charrs, salmonid

828

Hubley, P.B., Amiro, P.G., Gibson, A.J.F., Lacroix, G.L., and Redden, A.M. 2008. Survival and behaviour of migrating Atlantic salmon (Salmo salar L.) kelts in river, estuarine, and coastal habitat. ICES J. Mar. Sci. 65: 1626-1634.

Hutchings, J. A. 1986. Lakeward migrations by juvenile Atlantic salmon, Salmo salar. Can. J. Fish. Aquat. Sci. 43: 732-741. size, and reproduction on overwinter lipid depletion in brook trout. J. Fish Biol. 55(5): 1020-1028.

Hutchinson, G.E. 1957. A treatise on limnology, v. 1. Geography, Physics and Chemistry. Wiley. $1015 p$.

Irz, P., Odion, M., Argillier, C., and Pont, D. 2006. Comparison between the fish communities of lakes, reservoirs and rivers: can natural systems help define the ecological potential of reservoirs? Aquat. Sci. 68: 109-116.

Jansen, P. A., Slettvold, H., Finstad, A. G., and Langeland, A. 2002. Niche segregation between Arctic char (Salvelinus alpinus) and brown trout (Salmo trutta): an experimental study of mechanisms. Can. J. Fish. Aquat. Sci. 59(1): 6-11.

Jepsen, N., Aarestrup, K., Økland, F., and Rasmussen, G. 1998. Survival of radiotagged Atlantic salmon (Salmo salar L.)-and trout (Salmo trutta L.) smolts passing a reservoir during seaward migration. Hydrobiologia. 371: 347.

fishes of the genus Salvelinus. Dr. W. Junk, The Hague, The Netherlands. 
Johnson, W.E., and Groot, C. 1963. Observations on the migration of young sockeye salmon (Oncorhynchus nerka) through a large, complex lake system. J. Fish Res. Board Can. 20: 919-938.

832 Jonsson, B. and Jonsson, N. 2011. Ecology of Atlantic Salmon and Brown Trout: Habitat as a template for life histories, Fish and Fisheries Series, Volume 33. Springer, New York.

834 Jonsson, N., Hansen, L.P., and Jonsson, B. 1991. Variation in age, size and repeat spawning of adult Atlantic salmon in relation to river discharge. J. Anim. Ecol. 60: 937-947.

836 Jonsson, N., Jonsson, B., and Hansen, L.P. 1997. Changes in proximate composition and 837 estimates of energetic costs during upstream migration and spawning in Atlantic salmon Salmo salar. J. Anim. Ecol. 66: 425-436.

839 Jørgensen, E.H., Johansen, S.J.S., and Jobling, M. 1997. Seasonal patterns of growth, lipid deposition and lipid depletion in anadromous Arctic charr. J. Fish Biol. 51(2): 312-326.

841 Keefer, M. L., Clabough, T. S., Jepson, M. A., Bowerman, T., and Caudill, C. C. 2019. Temperature and depth profiles of Chinook salmon and the energetic costs of their long-

844 Kennedy, R.J., and Allen, M. 2016. The pre-spawning migratory behaviour of Atlantic salmon

846 Kennedy, R.J., Rosell, R., Millane, M., Doherty, D., and Allen, M. 2018. Migration and survival 847 of Atlantic salmon Salmo salar smolts in a large natural lake. J. Fish Biol. 93(1): 134-

849 Klemetsen, A., Amundsen, P. A., Dempson, J. B., Jonsson, B., Jonsson, N., O'Connell, M. F., 850 and Mortensen, E. 2003. Atlantic salmon Salmo salar L., brown trout Salmo trutta L. and 
Arctic charr Salvelinus alpinus (L.): a review of aspects of their life histories. Ecol. Freshw. Fish. 12: 1-59.

853 Landergren, P. and Vallin, L. 1998. Spawning of sea trout, Salmo trutta L., in brackish waters854 lost effort or successful strategy? Fish. Res. 35: 229-236.

855 Lennox, R.J., Gallagher, A.J., Ritchie, E.G., and Cooke, S.J. 2018. Evaluating the efficacy of 856 predator removal in a conflict-prone world. Biological Conservation, 224, 277-289.

857 Leonetti, F.E. 1997. Estimation of surface and intragravel water flow at sockeye salmon spawning beaches in Iliamna Lake, Alaska. N. Am. J. Fish. Manage. 17: 194-201.

859 Limburg, K.E., Landergren, P., Westin, L., Elfman, M., and Kristiansson, P. (2001). Flexible modes of anadromy in Baltic sea trout: making the most of marginal spawning streams. J. Fish Biol. 59: 682-695.

862 Lunde, R. 2014. Lake-habitat use of post-juvenile sea trout over time and space-An acoustic telemetry study in a regulated river (Master's thesis, Norwegian University of Life

Mahlum, S., Skoglund, H., Wiers, T., Norman, E.S., Barlaup, B.T., Wennevik, V., ... and Vollset, K. W. (2019). Swimming with the fishes: validating drift diving to identify

868 Mathes, M. T., Hinch, S. G., Cooke, S. J., Crossin, G. T., Patterson, D. A., Lotto, A. G., and 869 Farrell, A. P. 2010. Effect of water temperature, timing, physiological condition, and lake thermal refugia on migrating adult Weaver Creek sockeye salmon (Oncorhynchus nerka). Can. J. Fish. Aquat. Sci. 67: 70-84. 
872 McCormick, S.D. and Björnsson, B.T. 1994. Physiological and hormonal differences among

873 Atlantic salmon parr and smolts reared in the wild, and hatchery smolts. Aquaculture.

874 121: $235-244$.

875 McCusker, M. R., Parkinson, E., \& Taylor, E. B. 2000. Mitochondrial DNA variation in rainbow 876 trout (Oncorhynchus mykiss) across its native range: testing biogeographical hypotheses

877 and their relevance to conservation. Mol. Eocl. 9: 2089-2108.

878 Minke-Martin, V., Hinch, S.G., Braun, D.C., Burnett, N.J., Casselman, M.T., Eliason, E.J., and

879 Middleton, C.T. 2018. Physiological condition and migratory experience affect fitness-

880 related outcomes in adult female sockeye salmon. Ecol. Freshw. Fish. 27: 296-309.

881 Monsen, G. J. 2019. Behavioral study of coexisting populations of anadromous brown trout and

882 arctic char that overwinter in a subarctic lake (Master's thesis, Norwegian University of

$883 \quad$ Life Sciences, ̊̊s).

884 Moore, J. S., Harris, L. N., Le Luyer, J., Sutherland, B. J., Rougemont, Q., Tallman, R. F., ... \& 885 Bernatchez, L. 2017. Migration harshness drives habitat choice and local adaptation in anadromous Arctic char: Evidence from integrating population genomics and acoustic

888 Mulder, I.M., Morris, C.J., Dempson, J.B., Fleming, I.A., and Power, M. 2018. Overwinter thermal habitat use in lakes by anadromous Arctic char. Can. J. Fish. Aquat. Sci. 75(12:

891 Murphy, C.A., Arismendi, I., Taylor, G.A., and Johnson, S.L. 2019. Evidence for lasting 892 alterations to aquatic food webs with short-duration reservoir draining. PloS One 14: $893 \quad \mathrm{e} 0211870$. 
894

895

896

897

898

899

900

901

902

903

904

905

906

907

908

909

910

911

912 Olafsson, K., Pampoulie, C., Hjorleifsdottir, S., Gudjonsson, S., and Hreggvidsson, G. O. 2014.

913

914

915

916

Myers, R.A., Hutchings, J.A., and Gibson, R.J. 1986. Variation in male parr maturation within and among populations of Atlantic salmon, Salmo salar. Can. J. Fish. Aquat. Sci. 43(6): 1242-1248.

Narver, D. W. (1970). Diel vertical movements and feeding of underyearling sockeye salmon and the limnetic zooplankton in Babine Lake, British Columbia. J. Fish. Board Can. 27: 281-316.

Naughton, G. P., Keefer, M. L., Clabough, T. S., Knoff, M. J., Blubaugh, T. J., Sharpe, C., and Caudill, C. C. 2018. Reservoir provides cool-water refuge for adult Chinook salmon in a trap-and-haul reintroduction program. Mar. Freshw. Res. 69: 1995-2007.

Nelson-Chorney, H. T., Davis, C. S., Poesch, M. S., Vinebrooke, R. D., Carli, C. M., and Taylor, M. K. 2019. Environmental DNA in lake sediment reveals biogeography of native genetic diversity. Front. Ecol. Environ. 17: 313-318.

Newell, J. C., and Quinn, T. P. 2005. Behavioral thermoregulation by maturing adult sockeye salmon (Oncorhynchus nerka) in a stratified lake prior to spawning. Can. J. Zool. 83: 1232-1239.

O’Connell, M.F., and Ash, E.G. 1989. Atlantic salmon (Salmo salar) smolt production in a Newfoundland river system characterized by lacustrine habitat. Int. Rev. ges. Hydrobiol. Hydrogr. 74: 73-82.

Present-day genetic structure of Atlantic salmon (Salmo salar) in Icelandic rivers and icecap retreat models. PloS One. 9: e86809.

Pepper, V. A., Oliver, N. P., and Blundon, R. 1985. Juvenile anadromous Atlantic salmon of three lakes of Newfoundland. Int. Rev. Ges. Hydrobiol. Hydrogr. 70: 733-753. 
917 Peterson, R.H. and Gale, D. 1991. Fish species associations in riffle habitat of streams of varying 918 size and acidity in New Brunswick and Nova Scotia. J. Fish Biol. 38: 859-871.

919 Poe, T.P., Hansel, H.C., Vigg, S., Palmer, D.E., and Prendergast, L.A. 1991) Feeding of 920 predaceous fishes on out-migrating juvenile salmonids in John Day Reservoir, Columbia 921 River. Trans. Am. Fish. Soc. 120: 405-420.

922 Power, G. 2002. Charrs, glaciations and seasonal ice. In Ecology, Behaviour and Conservation of 923 the Charrs, Genus Salvelinus (pp. 17-35). Springer, Dordrecht.

924 Primmer, C.R., Veselov, A.J., Zubchenko, A., Poututkin, A., Bakhmet, I., and Koskinen, M.T. 925 2006. Isolation by distance within a river system: genetic population structuring of 926 Atlantic salmon, Salmo salar, in tributaries of the Varzuga River in northwest Russia. $927 \quad$ Mol. Ecol. 15: 653-666.

928 Prowse, T. D., and Brown, K. 2010. Hydro-ecological effects of changing Arctic river and lake 929 ice covers: a review. Hydrol. Res. 41: 454-461.

930 Prystay, T.S., de Bruijn, R., Peiman, K.S., Hinch, S.G., Patterson, D.A., Farrell, A.P., Eliason 931 E.J., and Cooke, S.J. 2020. Cardiac performance of free-swimming wild sockeye salmon 932 during the reproductive period. Integr. Org. Biol. 2: obz031.

933 Pulg, U., Vollset, K. W., and Lennox, R. J. 2019. Linking habitat to density-dependent 934 population regulation: How spawning gravel availability affects abundance of juvenile 935 salmonids (Salmo trutta and Salmo salar) in small streams. Hydrobiologia. 841: 13-29. 936 Quinn, T.P., Hodgson, S., and Peven, C. 1997. Temperature, flow, and the migration of adult 937 sockeye salmon (Oncorhynchus nerka) in the Columbia River. Can. J. Fish. Aquat. Sci. $938 \quad 54: 1349-1360$ 
939 Raleigh, R.F. 1967. Genetic control in the lakeward migrations of sockeye salmon

940 (Oncorhynchus nerka) fry. J. Fish Res. Board Can. 24: 2613-2622.

941 Reed, T. E., de Eyto, E., O’Higgins, K., Gargan, P., Roche, W., White, J., ... and McGinnity, P.

942 2017. Availability of holding habitat in lakes and rivers affects the incidence of spring

943 (premature) upriver migration by Atlantic salmon. Can. J. Fish. Aquat. Sci. 74: 668-679.

944 Richardson, N., Beaudreau, A. H., Wipfli, M. S., and Finkle, H. 2017. Prey partitioning and use

945 of insects by juvenile sockeye salmon and a potential competitor, threespine stickleback,

946 in Afognak Lake, Alaska. Ecol. Freshw. Fish. 26(4): 586-601.

947 Richter, A., and Kolmes, S. A. 2005. Maximum temperature limits for Chinook, coho, and chum

948 salmon, and steelhead trout in the Pacific Northwest. Rev. Fish. Sci. 13(1): 23-49.

949 Roscoe, D. W., Hinch, S. G., Cooke, S. J., and Patterson, D. A. 2010. Behaviour and thermal

950 experience of adult sockeye salmon migrating through stratified lakes near spawning

951 grounds: the roles of reproductive and energetic states. Ecol. Freshw. Fish. 19(1): 51-62.

952 Rühland, K., Paterson, A. M., and Smol, J. P. 2008. Hemispheric-scale patterns of climate-

953 related shifts in planktonic diatoms from North American and European lakes. Glob.

$954 \quad$ Change. Biol. 14(11): 2740-2754.

955 Scheuerell, M.D. and Schindler, D.E. 2003. Diel vertical migration by juvenile sockeye salmon:

956 empirical evidence for the antipredation window. Ecology. 84: 1713-1720.

957 Schwinn, M., Baktoft, H., Aarestrup, K., Lucas, M. C., and Koed, A. 2018. Telemetry

958 observations of predation and migration behaviour of brown trout (Salmo trutta) smolts

959 negotiating an artificial lake. Riv. Res. Appl. 34(8): 898-906.

960 Sigurjónsdóttir, H., and Gunnarsson, K. 1989. Alternative mating tactics of arctic charr,

961 Salvelinus alpinus, in Thingvallavatn, Iceland. Environ. Biol. Fish. 26: 159-176. 
962 Stearns, S. C. (1992). The evolution of life histories. Oxford, UK: Oxford University Press.

963 Stephens, P.A., Boyd, I.L., McNamara, J.M., and Houston, A.I. 2009. Capital breeding and

964 income breeding: their meaning, measurement, and worth. Ecology. 90: 2057-2067.

965 Svenning, M. A., and Gullestad, N. (2002). Adaptations to stochastic environmental variations:

966 the effects of seasonal temperatures on the migratory window of Svalbard Arctic charr. In

967 Ecology, behaviour and conservation of the charrs, genus Salvelinus (pp. 165-174).

$968 \quad$ Springer, Dordrecht.

969 Swales, S., Caron, F., Irvine, J. R., and Levings, C. D. 1988. Overwintering habitats of coho

970 salmon (Oncorhynchus kisutch) and other juvenile salmonids in the Keogh River system,

971 British Columbia. Can. J. Zool. 66: 254-261.

972 Thorpe, J. E., Ross, L. G., Struthers, G., and Watts, W. 1981. Tracking Atlantic salmon smolts,

973 Salmo salar L., through Loch Voil, Scotland. J. Fish Biol. 19(5): 519-537.

974 Thorstad, E. B., Whoriskey, F., Uglem, I., Moore, A., Rikardsen, A. H., and Finstad, B. 2012. A

975 critical life stage of the Atlantic salmon Salmo salar: Behaviour and survival during the

976 smolt and initial post-smolt migration. J. Fish Biol. 81(2): 500-542.

977 Ueda, H., Kaeriyama, M., Mukasa, K., Urano, A., Kudo, H., Shoji, T., Tokymitsu, Y.,

978 Yamauchi, K., and Kurihara, K. 1998. Lacustrine sockeye salmon return straight to their

979 natal area from open water using both visual and olfactory cues. Chem. Sens. 23: 207-

980212.

981 Verpoorter, C., Kutser, T., Seekell, D.A., and Tranvik, L. J. 2014. A global inventory of lakes

982 based on high-resolution satellite imagery. Geophys. Res. Lett. 41: 6396-6402. 
983 Vähä, J. P., Erkinaro, J., Niemelä, E., and Primmer, C. R. 2008. Temporally stable genetic 984 structure and low migration in an Atlantic salmon population complex: implications for 985 conservation and management. Evol. Appl. 1: 137-154.

986 Wetzel, R. G. 2001. Limnology: Lake and river ecosystems. Gulf Professional Publishing.

987 Wright, D.W., Stien, L.H., Dempster, T., and Oppedal, F. 2019. Differential effects of internal 988 tagging depending on depth treatment in Atlantic salmon: a cautionary tale for aquatic 989 animal tag use. Curr. Zool. 65: 665-673.

990 Young, D.B. and Woody, C.A. 2007. Dynamic in-lake spawning migrations by female sockeye 991 salmon. Ecol. Freshw. Fish. 16(2): 155-164.

992 Zhivotovsky, L.A., Fedorova, L.K., Rubtsova, G.A., Shitova, M.V., Rakitskaya, T.A., 993 Prokhorovskaya, V.D., Smirnov, B.P., Kaev, A.M., Cjupakhin, V.M., Samarsky, V.G., 994 Pogodin, V.P., Borozov, S.I., and Afanasiev, K.I. 2012. Rapid expansion of an enhanced 995 stock of chum salmon and its impacts on wild population components. Environ. Biol.

$996 \quad$ Fish. 94:249-258.

997 
$998 \quad$ Figures

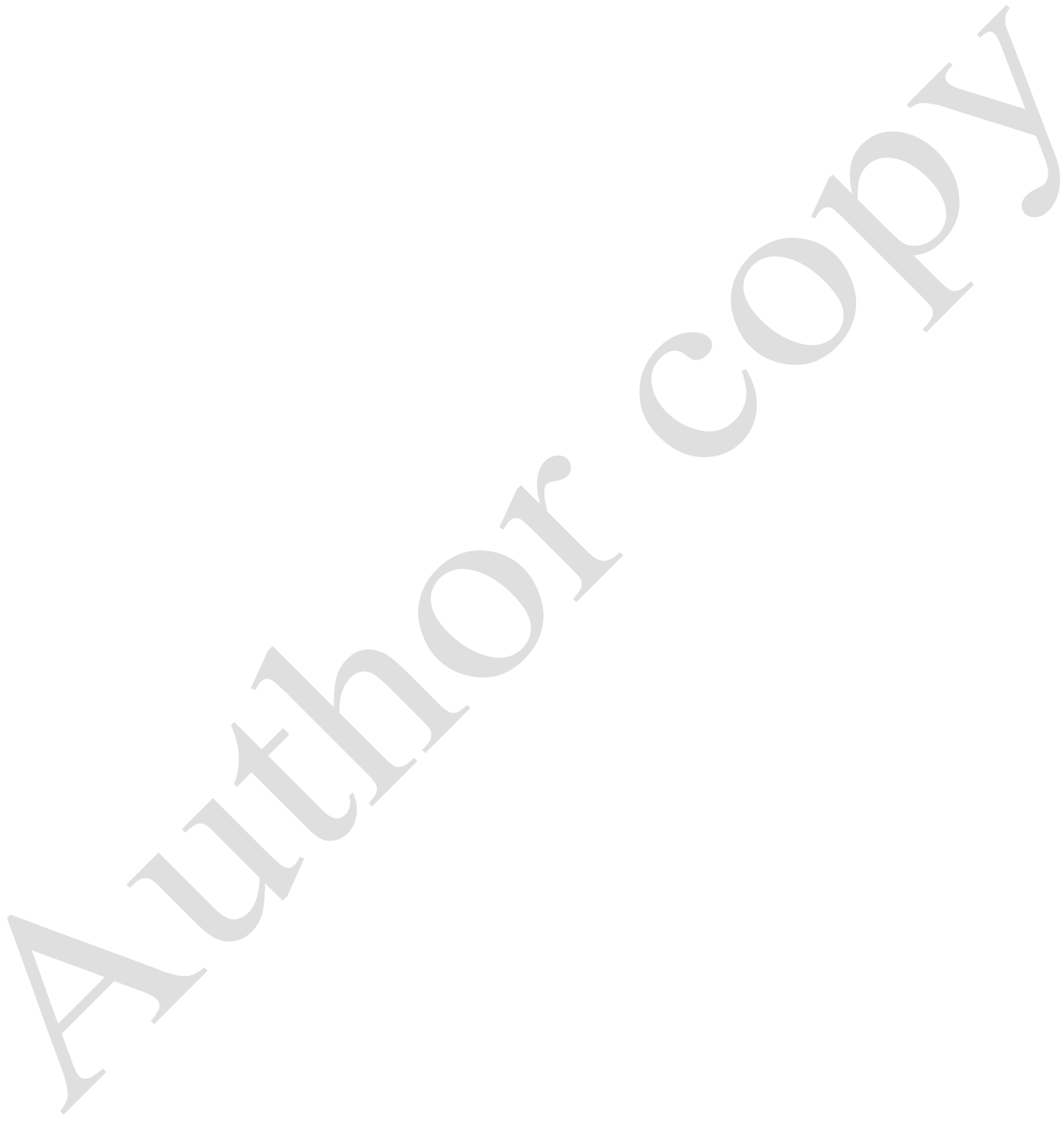




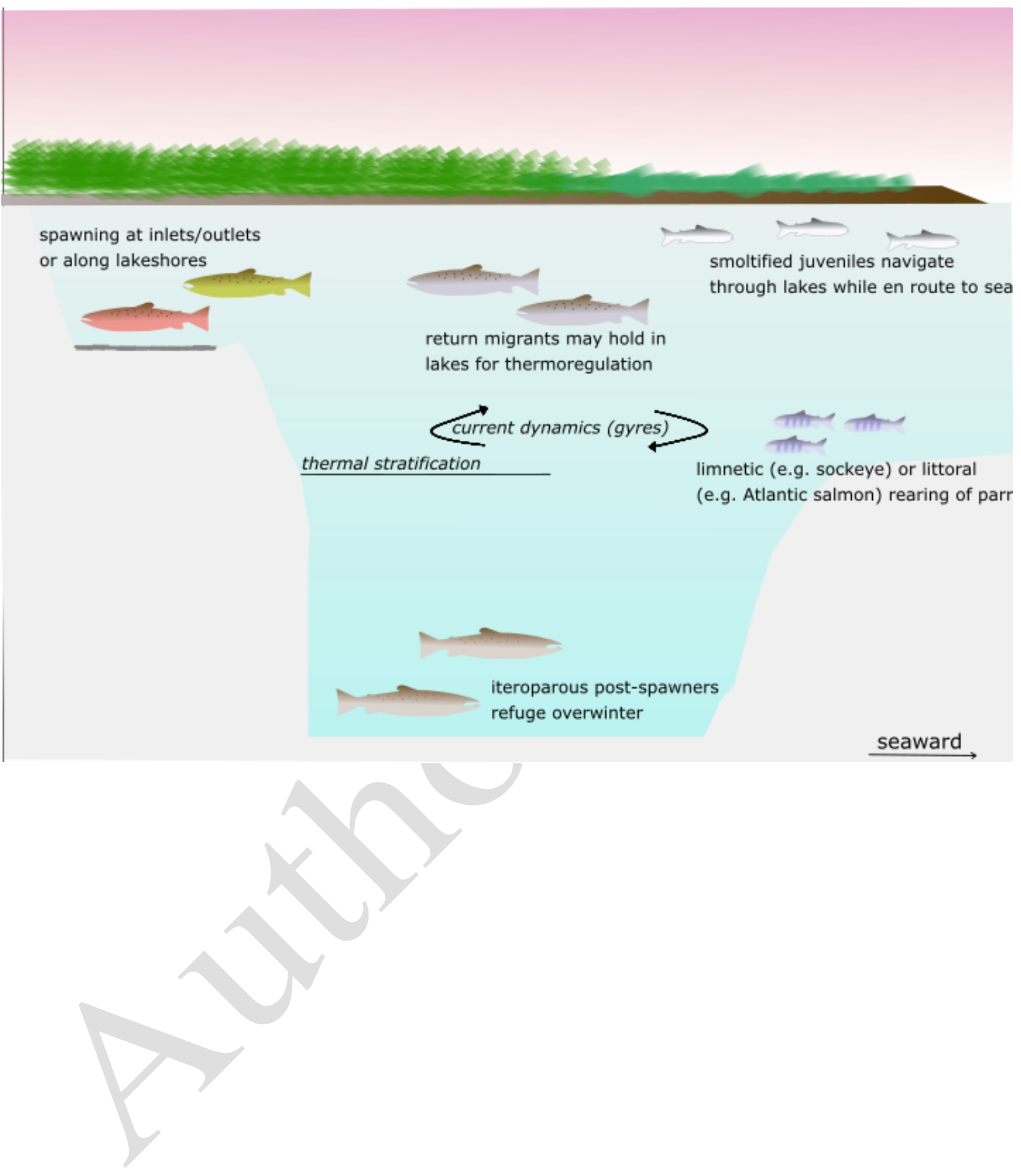




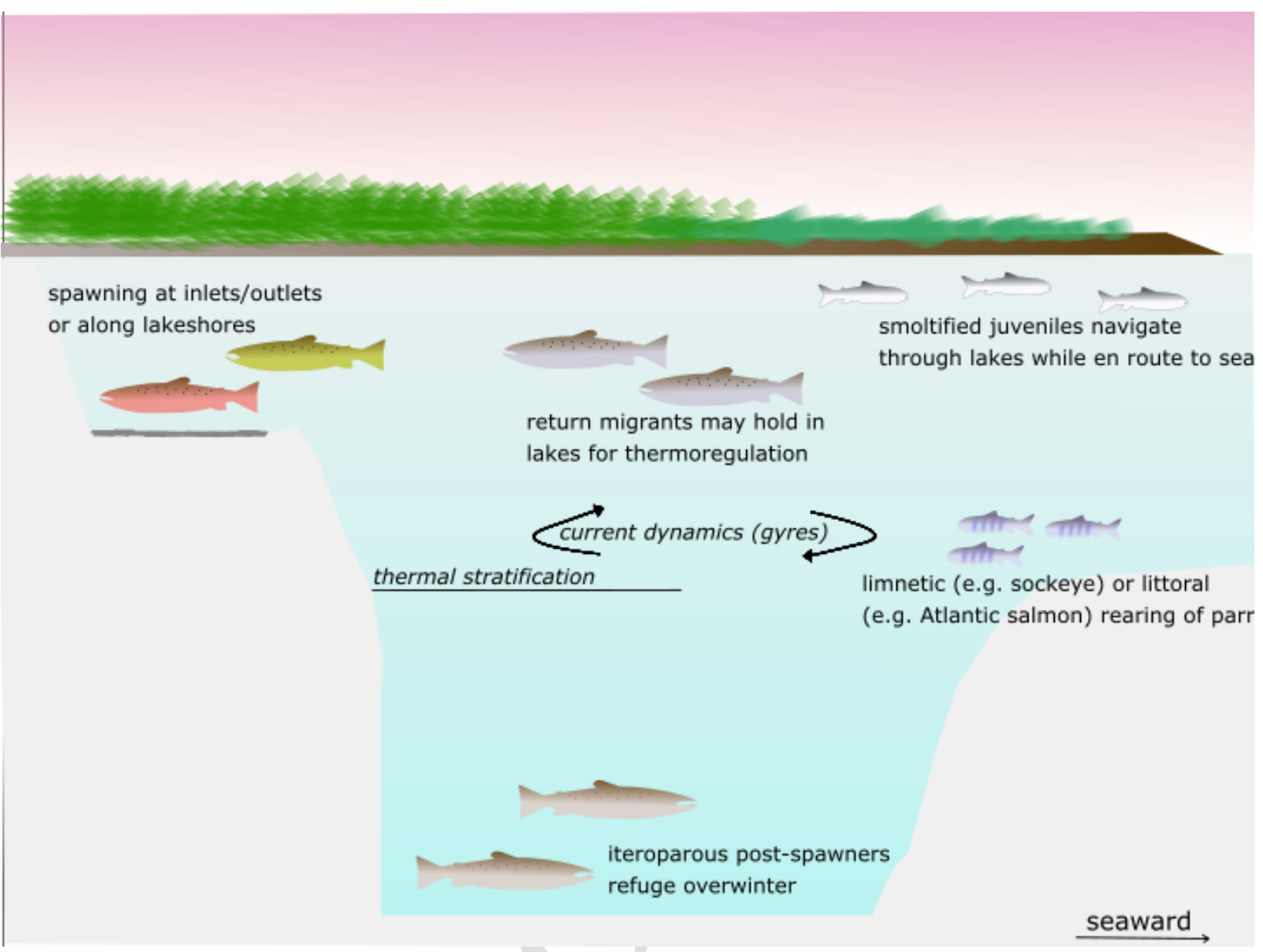

1002 Figure 1. Illustration of an anadromous lake with generic salmonids. We find that some species

1003 use the lake for rearing, especially sockeye (limnetic) and Atlantic salmon and brown trout

1004 (littoral) before smoltifying. Smolts moving down to sea through lakes may be challenged to

1005 navigate based on current dynamics that form and thermal stratification. However, adults can

1006 benefit from thermal stratification to behaviourally thermoregulate, especially sockeye. Only

1007 sockeye are known to spawn inside lakes along shore, but other species use inlets and outlets.

1008 Iteroparous Atlantic salmon and brown trout overwinter in lakes before returning to sea to

1009 recondition. There is still much more to learn about salmonids in anadromous lakes that can expand

1010 on this relatively rudimentary understanding of their role in the life cycle. 
1012

1013

1014

1015

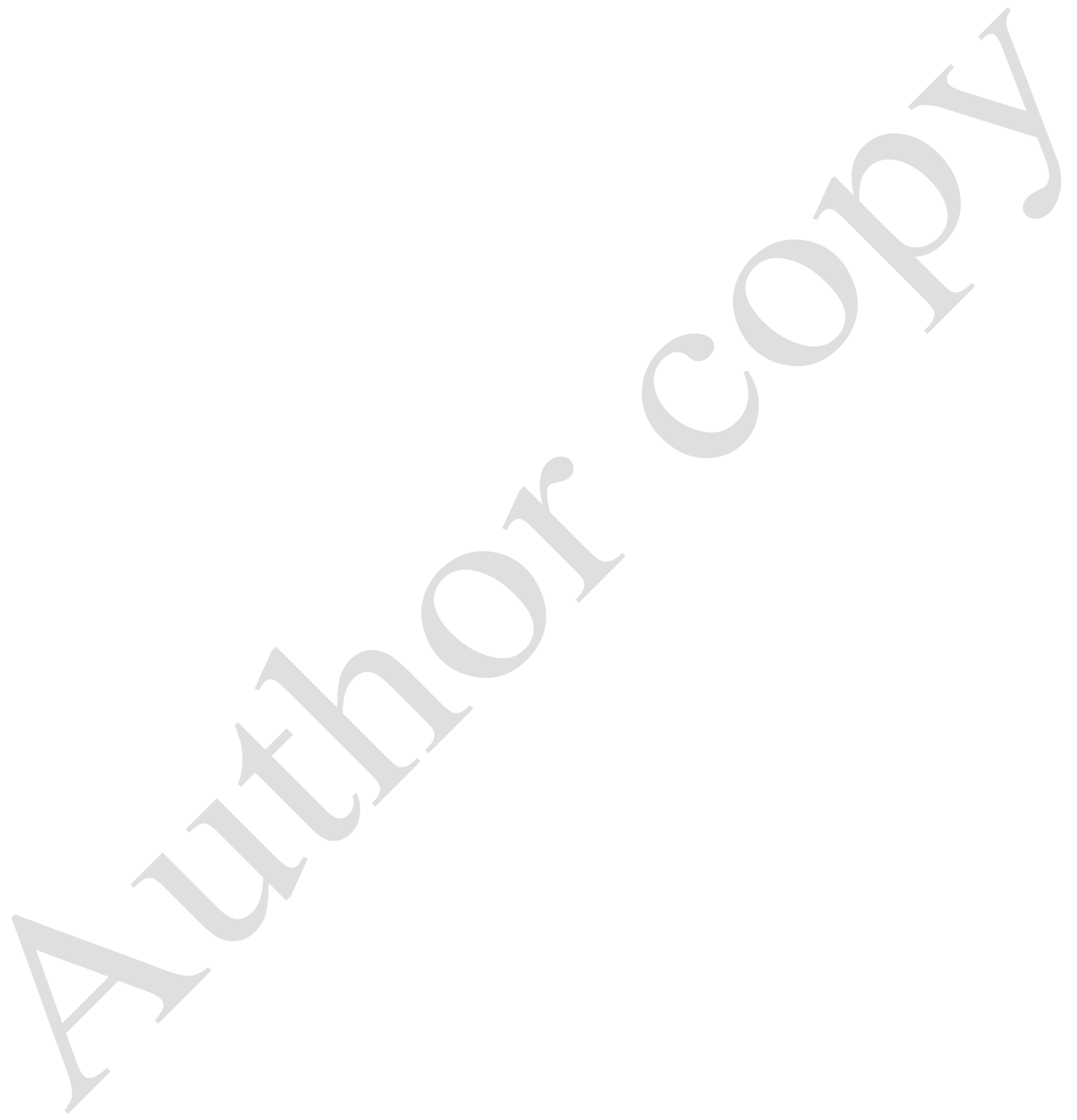

